GRASAS Y ACEITES 71 (2)

April-June 2020, e360

ISSN-L: 0017-3495

https://doi.org/10.3989/gya.0107191

\title{
Effect of screw-press extraction process parameters on the recovery and quality of pistachio oil
}

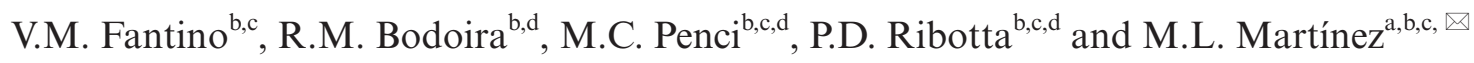

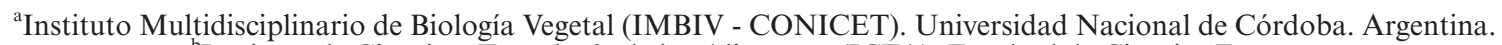 \\ ${ }^{b}$ Instituto de Ciencia y Tecnología de los Alimentos (ICTA). Facultad de Ciencias Exactas \\ Físicas y Naturales (FCEFyN). Universidad Nacional de Córdoba (UNC). Argentina. \\ ${ }^{c}$ Departamento de Química Industrial y Aplicada. Facultad de Ciencias Exactas. Físicas y \\ Naturales (FCEFyN). Universidad Nacional de Córdoba (UNC). Argentina. \\ ${ }^{\mathrm{d}}$ Instituto de Ciencia y Tecnología de los Alimentos Córdoba (ICYTAC - CONICET). \\ Universidad Nacional de Córdoba (UNC). Argentina. \\ Corresponding author: marcela.martinez@unc.edu.ar
}

Submitted: 14 January 2019; Accepted: 11 June 2019; Published online: 17 June 2020

SUMMARY: Pistachio nuts have high economical and nutritional value, mostly due to their elevated oil content $(50 \%)$, which is composed mainly of oleic and linoleic fatty acids. Box-Behnken experimental designs were performed to optimize the oil extraction by response surface analysis. The independent variables measured were seed moisture content (SMC), restriction die (RD), screw press speed (PS) and pressing temperature (PT), while the response variables considered were oil recovery (OR), fine solid contents in the oil (FSC), oil remaining in the cake (OC) and parameters related to oil quality (free fatty acid composition (FFAC, $\mathrm{mg} \mathrm{KOH} / \mathrm{g}$ oil), peroxide value (PV, meq $\mathrm{O}_{2} / \mathrm{kg}$ oil), $\mathrm{K}_{232}, \mathrm{~K}_{270}$ and pigment contents, $\mathrm{mg} / \mathrm{kg}$ oil). Given that the chemical quality of pistachio nut oil pressed under different conditions was not affected, the process response was optimized in order to maximize OR under two pressing temperatures. Therefore, at $75^{\circ} \mathrm{C}$, pistachio oil extraction showed a maximum OR (79.61 g/100 g oil) at 8\% SMC, $4 \mathrm{~mm} \mathrm{RD}$ and $20 \mathrm{rpm}$ SP; while, under cold-pressed conditions, the maximum OR $(65.97 \mathrm{~g} / 100 \mathrm{~g}$ oil) was achieved at 10\% SMC, 4mm RD and $20 \mathrm{rpm}$ SP. It is important to highlight that OR values were higher than the results reported previously and the chemical quality parameters from both oils were in the range of Codex standards for virgin (non-refined) oils (FFAC $<0.31$ and PV $<0.33$ ).

KEYWORDS: Chemical quality parameters; Oil recovery; Pistachio oil; Screw-press extraction

RESUMEN: Efecto de los parámetros del proceso de extracción por prensado sobre el rendimiento y la calidad de aceite de Pistacho. Los frutos de pistacho son altamente nutritivos, principalmente debido a su contenido de aceite $(50 \%)$, compuesto principalmente por ácidos grasos mono y di-insaturados. Con la finalidad de conocer las condiciones de proceso adecuadas que permitan maximizar la cantidad de aceite extraído preservando la calidad química del mismo se utilizaron dos diseños experimentales de Box-Behnken. Las variables independientes analizadas fueron la humedad de la semilla (HS), el diámetro de reducción (DR), la velocidad y temperatura de prensado (VP y TP, respectivamente), mientras que las variables de respuesta fueron el rendimiento en aceite (RA), el contenido de sólidos finos en el aceite (CFA), el aceite remanente en torta (AT) y parámetros relacionados con la calidad (composición en ácidos grasos libres (CAGL, mg KOH/g aceite), índice de peróxido (IP, meqO $/ 2 / \mathrm{kg}$ aceite), $\mathrm{K}_{232}, \mathrm{~K}_{270}$ y pigmentos (mg/ $\mathrm{kg}$ aceite)). La calidad química de los aceites obtenidos no mostró daño oxidativo y/o hidrolítico significativo bajo las diferentes condiciones del proceso (IP $<0.33$ y CAGL $<0.31$, respectivamente), por lo tanto, la respuesta se optimizó para maximizar RA a dos TP, 75 y $40{ }^{\circ} \mathrm{C}$. El rendimiento en aceite se maximizó ajustando HS ( $8 \%$ ó 10\% b.h.), DR (4 mm), VP (20 rpm) a ambas temperaturas, alcanzando extracciones de aceite de $79.61 \%$ y $65.97 \%$, respectivamente.

PALABRAS CLAVE: Aceite de pistacho; Extracción por prensado; Parámetros de calidad química; Rendimiento de aceite

ORCID ID: Fantino VM https://orcid.org/0000-0003-3157-5037, Bodoira RM https://orcid.org/0000-0002-3808-7899, Penci MC https://orcid.org/0000-0003-4953-4356, Ribotta PD https://orcid.org/0000-0001-7883-8856, Martínez ML https://orcid.org/0000-0002-6236-7903

Citation/Cómo citar este artículo: Fantino VM, Bodoira RM, Penci MC, Ribotta PD, Martínez ML. 2020. Effect of screw-press extraction process parameters on the recovery and quality of pistachio oil. Grasas Aceites 71 (2), e360. https://doi.org/10.3989/gya.0107191

Copyright: C2020 CSIC. This is an open-access article distributed under the terms of the Creative Commons Attribution 4.0 International (CC BY 4.0) License. 


\section{INTRODUCTION}

Regarding the nutritional value of natural products, tree nuts rank third after fruits and spices for containing the most phytochemicals (Pérez-Jiménez et al., 2010). Within these trees, the pistachio (Pistacia vera L.) is a member of the Anacardiaceae family, native to Central and Western Asia. Their fruits contain seeds that are widely consumed as snacks (roasted, natural or salted-roasted) and as components of several edible products (Martínez et al., 2016). Thus, in recent years, this crop has been introduced in some countries in America, such as Argentina, Chile and in the United States. The total pistachio production is estimated at an average of 3500-4000 MT annually (Chang et al., 2016).

Pistachio nuts are highly nutritious, mainly due their elevated lipid and protein contents (46- $67 \mathrm{~g} / \mathrm{kg}$ and $20-25 \mathrm{~g} / \mathrm{kg}$ of nut weight, respectively) (Bullo et al., 2015). These nuts also contain 14\% carbohydrates, $1 \%$ fibers, minerals (mainly potassium), vitamins ( $\beta$ carotene, thiamine, riboflavin, tocopherols and ascorbic acid) and other water-soluble compounds, such as polyphenols and pigments, which have been associated with health benefits (Tsantili et al., 2010; Schulze-Kaysers et al., 2015).

In addition, many works highlight the quality of pistachio oil for use in food (Ventakatachalam and Sathe, 2006; Chahed et al., 2008; Tsantili et al., 2010; Ojeda-Amador et al., 2018a) due its fatty acid profile which is composed mainly of oleic acid (52\% to $72 \%$ ) and linoleic acid (12\% to $31 \%$ ) (Arena et al., 2007; Sena-Moreno et al., 2015). The presence of minor bioactive compounds in pistachio oil, such as phytosterols and phenols, has also been reported previously (Tomaino et al., 2010).

Previous works showed that pistachio oil recovery and composition, such as polyphenol and tocopherol contents, were affected by the extraction process (Sena Moreno et al., 2015). These authors concluded that solvent extraction was the best o among the methods analyzed. However, it is important to note that the oil obtained by this process presented lower sensory and chemical qualities due to the presence of undesirable flavors and the reduction in the contents of vitamins and phenolic compounds (Abdolshahi et al., 2015). Supercritical fluids is an alternative method for replacing or complementing conventional industrial oil extraction processes such as solvent extraction, and permits the extractions to be carried out at lower temperatures, achieving high oil recovery with good chemical quality (Jokic et al., 2014). However, the heightened costs associated with processing are the greatest limitation associated with this extraction method.

In this context, the screw-press extraction technique is as an alternative process to solvent removal, especially for specialty oils because it provides an easy and reliable method of processing seeds and nuts with high oil contents (Wiesenborn et al., 2001; Singh et al., 2002; Zengh et al., 2003; Martínez et al., 2008; 2012; 2013; 2017a; 2107b). There are previous studies in which pistachio oil extraction by pressing was analyzed (Alvarez-Ortí et al., 2012; Sena Moreno et al., 2015; Ling et al., 2016; Rabadán et al., 2017; Ojeda-Amador et al., 2018b). Particularly, Rabadán et al., (2017) and Alvarez-Ortí et al., (2012) compared hydraulic and screw-press, and concluded that a higher oil recovery (70 and 40\%, respectively) was obtained by screw pressing regardless of the processing conditions. The oils did not present differences in chemical quality parameters in wither of the evaluated methods. Ojeda-Amador et al., (2018b) mainly studied the influence of several processing conditions, including roasting, temperature, restriction die and screw-press speed, on the minor components contained in virgin pistachio oils. Sena-Moreno et al., (2015) evaluated the effect of the drying temperature of pistachio nuts on the sensory and physicochemical characteristics of the oils, as well as the chemical composition. Finally, Ling et al., (2016) analyzed the effects of different roasting treatments applied before screw pressing on oil quality.

Nevertheless, it is important to highlight that these authors did not make a systematic study of all the variables that influence the screw-press extraction efficiency (oil recovery and fine solids coextracted with the oil) or the chemical quality of the oils obtained under each processing condition.

Screw-press performance strongly depends on the type of raw material (Mattea 1999, Martínez and Maestri, 2015) and the conditioning methods. The extraction process parameters for a given raw material must be determined due the fact that it is not feasible to assume a similar behavior even when comparing among nuts or oilseeds. Regarding the method for preparing the raw material, it consists of a number of unit operations such as cooking, cracking, flaking, moistening or drying, among others (Wiesenborn et al., 2001; Martínez et al., 2008; 2012; 2013; Savoire et al., 2013; Martínez and Maestri, 2015; Martínez et al., 2017a; 2017b). In fact, seed moisture content appears to be a key process variable that should be determined for each given nut or oilseed (Singh and Bargale, 1990; 2000; Hamm and Hamilton, 2000; Singh et al., 2002; Martínez et al., 2008; 2012; 2013; 2017a; 2017b). Singh and Bargale $(1990,2000)$ have observed maximum oil recoveries at 7\% (wet basis) moisture content for water-soaked linseed, and at $7.5 \%$ for rapeseed, in a moisture content range of $5-12 \%$ (wet basis). Martínez et al., 2008, 2012, 2013 and $2017 \mathrm{~b}$, reported that moisture content was one of the most important factors affecting walnut, chia, almond and sesame oil extraction, with 7.5, 10, 8, and $12.3 \%$ (wet basis) moisture as the optimal values, respectively. 
Considering that several factors may significantly influence the extraction efficiency and the oil chemical quality in oil pressing and extraction processes, the response surface methodology is often applied in order to evaluate the individual and combined effect of each process parameter on the pressing process and quality of the oil (Akinoso and Raji 2011; Martínez et al., 2012; Martínez and Maestri 2015).

Taking into account the above cited, the objective of the present work was to analyze the effect of extraction parameters of raw pistachio nuts on oil recovery (OR) and physical-chemical quality through screw-pressing. The experimental designs included different levels of the process variables, seed moisture content (SMC), pressing temperature (PT) and speed (PS), and restriction die (RD) in order to optimize OR and oil quality in a pilot scale screw press.

\section{MATERIALS AND METHODS}

\subsection{Nut materials and moisture content}

Pistachio nuts (Pistacia vera $\mathrm{L}$. cv. Kerman) were harvested at full maturity from commercial plantations in the San Juan Province, Argentina. The nuts were cleaned, ground and screened to reach a particle size between 2.4 to $4.8 \mathrm{~mm}$. The initial moisture content was determined according to official methods (AOCS, 2009) and, in order to obtain the moisture content levels indicated for each experimental design, the nuts were hydrated following the methodology proposed by Martinez et al., (2008). The water-sprinkled samples were stored for 2 days before use in an air-tight metal container $(500 \mathrm{~g})$ to reach moisture equilibration. During this time the containers were shaken at regular intervals to distribute moisture uniformly throughout the sample. To regulate lower moisture content levels, the nuts were kept in a vacuum oven at $25{ }^{\circ} \mathrm{C}$ until the defined moisture was reached. The nuts contained $48.51 \pm 1.85 \%$ oil (Dry Basis: DB) and $3.79 \pm 0.23 \%$ initial moisture content (Wet Basis: WB).

\subsection{Screw-press extraction}

Oil extraction was carried out in a single step with a Komet screw press (Model CA 59G, IBG Monforts, Mönchengladbach, Germany). The press barrel had an effective and total length and an internal diameter of $3.1,7$, and $3.5 \mathrm{~cm}$, respectively. The screw had a length and diameter of 15 and $3 \mathrm{~cm}$, respectively. The first Box-Behnken experimental design included three levels of each following parameters: restriction die (RD: 4, 5 and $6 \mathrm{~mm}$ ); seed moisture content (SMC: 3,7 and $11 \%$ WB); pressing temperature (PT: 25,50 and $75^{\circ} \mathrm{C}$ ); and pressing speed (PS: 20, 40 and $60 \mathrm{rpm})$. After each run, all press devices were conditioned. The amount of nut sample pressed in each run was $200 \mathrm{~g}$. The screw-press components and the sample were first heated for $30 \mathrm{~min}$ to achieve the desired temperature. Temperature was constantly monitored during extraction with a digital thermometer (TES Thermometer 1307 Type K) inserted into the restriction die.

\subsection{Oil recovery and fine solids content}

The oil recovery (OR) was calculated taking into consideration the initial oil content in the raw material $(48.51 \%)$ and the oil remaining in cake (OC). It was expressed as g extracted oil/g oil initial x 100 (g/100 g oil). In both cases, oil contents were determined by Soxhlet extraction using $n$-hexane as solvent (AOCS, 2009).

The extracts obtained from each run were centrifuged at $13.000 \mathrm{rpm}$ for $15 \mathrm{~min}$. The precipitated solids were recovered, washed with $n$-hexane, dried and weighed. Fine solid content (FSC) was expressed as g solids/100 g extract (oil + solid) (Martínez et al., 2012).

\subsection{Oil analysis}

\subsubsection{Chemical quality parameters and fatty acid composition}

Free fatty acid content (FFAC) expressed as mg $\mathrm{KOH} / \mathrm{g}$ oil, peroxide value (PV) expressed as meq $\mathrm{O}_{2} / \mathrm{kg}$ oil, and specific extinction coefficients $\left(\mathrm{K}_{232}\right.$ and $\mathrm{K}_{270}$ ) were quantified according to standard methods (AOCS, 2009).

Fatty acid (FA) composition was analyzed according to procedures reported earlier (Maestri et al. , 2015) using gas chromatography (GC) (PerkinElmer, Shelton, CT, USA). The identification of FA was made by comparing their retention times with those of reference compounds and expressed as relative percentage $(\%)$.

\subsubsection{Minor compounds and oxidative stability}

The total phenol content (TPC) was determined by the Folin-Ciocalteau method according to Torres et al., (2009) using $20 \mathrm{~g}$ of oil and quantified by comparison of the absorbance value $(725 \mathrm{~nm})$ with those from a standard curve with gallic acid (GA). TPC was expressed as $\mathrm{mg} \mathrm{GA} / \mathrm{kg}$ oil. The quantification and identification of tocopherols were carried out using high pressure liquid chromatography (PerkinElmer, Shelton, CT, USA) according to AOCS methods (Ce 8-89, 2009) with some modifications. Samples of $1 \mathrm{~g}$ pistachio oil were placed in $10-\mathrm{mL}$ volumetric flasks. The required amount of $n$-hexane was added and swirled to dissolve into the sample. An aliquot of $20 \mu \mathrm{L}$ of this solution was injected onto 
a Supelcosil LC-NH2-NP column $(25 \mathrm{~cm}$ x $4.6 \mathrm{~mm}$, Supelco, Bellefonte, PA, USA). The mobile phase was $n$-hexane/ethyl acetate $(70 / 30 \mathrm{v} / \mathrm{v})$ with a flow rate of $1 \mathrm{~mL} / \mathrm{min}$. UV detection at $295 \mathrm{~nm}$ was performed. Individual tocopherols were identified by comparison of their retention times with those of authentic standards (CN Biomedicals, Costa Mesa, CA) and were quantified by the external standard method. Finally, pigments were measured spectrophotometrically according to Minguez-Mosquera et al., (1991). Both minor components were expressed as $\mathrm{mg} / \mathrm{kg}$ oil.

The oxidative stability index (OSI) was measured by the Rancimat (Metrohm, Herisau, Switzerland) method (Cd 12b-92 AOCS, 2009). The assay conditions were: $3.5 \mathrm{~g}$ oil; air flow rate of $20 \mathrm{~L} / \mathrm{h}$; and a temperature of the heating block of $110{ }^{\circ} \mathrm{C}$. The results were expressed as induction time (h), which corresponds to the break point in the plotted curves.

\subsection{Experimental design and response surface analysis}

Response surface methodology (RSM) was selected to model and optimize the extraction conditions for pistachio nut oil (Montgomery, 2005; Akinoso and Raji, 2011; Martínez et al., 2012; 2017a; 2017b; Martínez and Maestri, 2015). A BoxBehnken design was used to identify interactions among process parameters and response variables, as well as those conditions that optimized the oil extraction process.

First, an exploratory experimental array was carried out in order to define the range of process variables (Table 1). Three different levels were used for each of the following factors: seed moisture content (SMC) $\left(X_{I}, 3,7\right.$ and $\left.11 \%\right)$; restriction die (RD) $\left(X_{2}, 4,5\right.$ and $\left.6 \mathrm{~mm}\right)$; pressing temperature (PT) $\left(X_{3:} 25,50\right.$ and $\left.75^{\circ} \mathrm{C}\right)$; and pressing speed (PS) $\left(X_{4}: 20,40\right.$ and $\left.60 \mathrm{rpm}\right)$. In this preliminary assay the responses evaluated were only oil recovery (OR) $(\mathrm{g} / 100 \mathrm{~g}$ oil $)\left(Y_{1}\right)$ and fine solid contents (FSC) (g solids/100 g extract) $\left(Y_{2}\right)$.

Based on the conclusions determined from the preliminary test and so as to optimize the experimental conditions of the oil extraction process, a new Box-Behnken experimental design was made. In this second test the factors that significantly affected the OR were included. The evaluated responses in this design were: OR (g/100 g oil) $\left(Y_{l}\right)$; FSC (g solids/100 g extract) $\left(Y_{2}\right)$, oil remaining in cake (OC) $(\mathrm{g} / 100 \mathrm{~g}$ oil $)\left(Y_{3}\right)$; peroxide value $(\mathrm{PV})\left(\mathrm{meq} \mathrm{O}_{2} / \mathrm{kg}\right.$ oil) $\left(Y_{4}\right)$; free fatty acid content (FFAC) $(\mathrm{mg} \mathrm{KOH} / \mathrm{g}$ oil) $\left(Y_{5}\right)$; specific extinction coefficients $\mathrm{K}_{232}\left(Y_{6}\right)$ and $\mathrm{K}_{270}\left(Y_{7}\right)$; lutein content $(\mathrm{LC})(\mathrm{mg} / \mathrm{kg}$ oil $)\left(Y_{8}\right)$; and chlorophyll content $(\mathrm{CC})(\mathrm{mg} / \mathrm{kg}$ oil $)\left(Y_{9}\right)$.

In both Box-Behnken experimental designs, quadratic polynomials were fitted in order to express the responses $\left(Y_{n}\right)$ as a function of factors $\left(X_{i}\right)$; where the response is $Y$, the constant term is $\beta_{0}$, the coefficients of the linear parameters are represented by $\beta_{i}$, the factors are represented by $X_{i}$, the coefficients of the quadratic parameter are represented by $\beta_{i i}$, and the coefficients of the interaction parameters are represented by $\beta_{i j}$.

$$
Y=\beta_{0}+\sum_{i=1}^{3} \beta_{i} X_{i}+\sum_{i=1}^{3} \beta_{i i} X_{i}^{2}+\sum \sum_{i<j}^{3} \beta_{i j} X_{i} X_{j} \quad \text { Eqn. (1) }
$$

Two different designs were performed, the first one as exploratory (preliminary essays) and the second one, to define the optimal combination among the process extraction conditions. In both designs, the results were analyzed by a multiple regression method. The regression models were obtained from the experimental results. Performance of the model fitness was evaluated by ANOVA (Statgraphic Plus software v 5.1, USA). The coefficient of determination, $\mathrm{R}^{2}$, explains the extent of the variance in a modeled variable that can be explained by the model. Only models with high $\mathrm{R}^{2}$ were incorporated into this study. Only significant coefficients $(p<0.05)$ were included in the multiple regression equations. Three-dimensional response-surface graphics were created for each response variable. The determinations were made at least in duplicate, randomly, and replicas of the central point were performed to permit estimation of pure error as square sums. Statistical analysis of data was done by Statgraphic Plus software (v5.1, USA).

\section{RESULTS AND DISCUSSION}

In the first part, an experimental design of 28 treatments was developed (4 central points) with factors and levels previously described (Table 1). It is important to note that for the run with conditions $2,6,7$ and 10 , no extract was obtained. These results could be due to the combination of a low seed moisture content (SMC) and high pressing speed (PS), which did not provide the adequate conditions for pressing so the oil was not able to flow and leave the matrix. With regards to oil recovery (OR), the maximum value $(66.53 \mathrm{~g} / 100 \mathrm{~g}$ oil) was obtained in extraction 11 (Table 1), with a seed moisture content (SMC) of 7\%, a restriction die (RD) of $4 \mathrm{~mm}$, a pressing speed (PS) and temperature (PT) of $20 \mathrm{rpm}$ and $50{ }^{\circ} \mathrm{C}$, respectively. Treatments with SMC of $7 \%$ showed the highest variability (11.36-66.53 g/100 g oil). The ANOVA analysis determined that SMC $(p=0)$, PT $(p=0)$ and $\operatorname{RD}(p=0.0414)$ showed $p$-values lower than the level of significance $(p<$ $0.05)$; whereas PS did not have significant influence $(p=0.0554)$ (Table 2).

Figure 1 shows the individual effects of the process variables on OR. There were certain levels of SMC and PT which led to maximum OR values. 
TABLE 1. Box-Behnken exploratory assay. Effects of extraction variables on oil recovery (OR: $\mathrm{g} / 100 \mathrm{~g}$ oil) and fine solid contents (FSC:g solids $/ 100 \mathrm{~g}$ extract) in oil. $X_{1}$ : seed moisture (\%,WB), $X_{2}$ : restriction die $(\mathrm{mm}), X_{3}$ : pressing temperature $\left({ }^{\circ} \mathrm{C}\right)$ and $X_{4}$ : pressing speed (rpm).

\begin{tabular}{|c|c|c|c|c|c|c|}
\hline \multirow[b]{2}{*}{ Assay } & \multicolumn{4}{|c|}{ Factors } & \multicolumn{2}{|c|}{ Response variables } \\
\hline & $X_{1}$ & $X_{2}$ & $X_{3}$ & $X_{4}$ & OR & FSC \\
\hline 1 & 7 & 5 & 25 & 20 & $18.67 \pm 1.03$ & $6.86 \pm 0.49$ \\
\hline 2 & 7 & 5 & 25 & 60 & ND & ND \\
\hline 3 & 7 & 4 & 25 & 40 & $18.59 \pm 1.11$ & $6.57 \pm 0.45$ \\
\hline 4 & 7 & 6 & 25 & 40 & $11.36 \pm 0.87$ & $6.18 \pm 0.39$ \\
\hline $5^{\mathrm{b}}$ & 7 & 5 & 50 & 40 & $45.01 \pm 2.54$ & $7.39 \pm 0.4$ \\
\hline 6 & 3 & 5 & 25 & 40 & ND & ND \\
\hline 7 & 3 & 6 & 50 & 40 & ND & ND \\
\hline 8 & 3 & 4 & 50 & 40 & $7.09 \pm 0.76$ & $8.46 \pm 0.51$ \\
\hline 9 & 3 & 5 & 50 & 20 & $14.17 \pm 1.65$ & $10.32 \pm 0.55$ \\
\hline 10 & 3 & 5 & 50 & 60 & ND & ND \\
\hline 11 & 7 & 4 & 50 & 20 & $66.53 \pm 3.04$ & $4.38 \pm 0.36$ \\
\hline 12 & 7 & 6 & 50 & 20 & $55.86 \pm 1.54$ & $5.1 \pm 0.41$ \\
\hline $13^{\mathrm{b}}$ & 7 & 5 & 50 & 40 & $49.30 \pm 2.04$ & $5.81 \pm 0.43$ \\
\hline $14^{\mathrm{b}}$ & 7 & 5 & 50 & 40 & $53.88 \pm 2.01$ & $5.76 \pm 0.47$ \\
\hline $15^{\mathrm{b}}$ & 7 & 5 & 50 & 40 & $50.51 \pm 2.32$ & $6.63 \pm 0.45$ \\
\hline 16 & 7 & 4 & 50 & 60 & $56.07 \pm 1.89$ & $6.58 \pm 0.42$ \\
\hline 17 & 7 & 6 & 50 & 60 & $40.64 \pm 2.97$ & $6.61 \pm 0.37$ \\
\hline 18 & 7 & 4 & 75 & 40 & $61.83 \pm 2.99$ & $6.89 \pm 0.47$ \\
\hline 19 & 7 & 6 & 75 & 40 & $40.66 \pm 2.76$ & $7.19 \pm 0.48$ \\
\hline 20 & 3 & 5 & 75 & 40 & $22.94 \pm 1.89$ & $10.57 \pm 0.43$ \\
\hline 21 & 11 & 5 & 25 & 40 & $39.68 \pm 1.34$ & $4.34 \pm 0.38$ \\
\hline 22 & 11 & 4 & 50 & 40 & $58.86 \pm 1.78$ & $5.59 \pm 0.42$ \\
\hline 23 & 11 & 6 & 50 & 40 & $45.54 \pm 2.43$ & $4.35 \pm 0.37$ \\
\hline 24 & 11 & 5 & 50 & 20 & $58.03 \pm 2.76$ & $3.79 \pm 0.29$ \\
\hline 25 & 11 & 5 & 50 & 60 & $55.01 \pm 1.98$ & $7.39 \pm 0.48$ \\
\hline 26 & 7 & 5 & 75 & 60 & $48.99 \pm 2.55$ & $7.28 \pm 0.37$ \\
\hline 27 & 11 & 5 & 75 & 40 & $55.03 \pm 2.43$ & $4.86 \pm 0.34$ \\
\hline 28 & 7 & 5 & 75 & 20 & $57.09 \pm 2.76$ & $6.34 \pm 0.38$ \\
\hline
\end{tabular}

${ }^{\mathrm{b}}$ Central points. Mean values ( \pm standard deviation) were the averages of two independent measurements. ND: not detected.

However, in the case of RD and PS, negative effects were observed, since less compression of material was generated and a shorter residence time of the material inside the pressing chamber resulted in reductions in OR. For walnut oil, similar trends for SMC were obtained at pilot and industrial scale extraction conditions (Martínez et al., 2008; 2017a). By increasing SMC from 2.5 to $7.5 \%$ and 5.5 to $10 \%$ (WB) these authors observed an increase in walnut $\mathrm{OR}$ at pilot scale extractions from 61 to $83.5 \%$ (at $25{ }^{\circ} \mathrm{C}$ ) and from 64.7 to $89.3 \%$ (at $50{ }^{\circ} \mathrm{C}$ ); and at industrial scale extraction from 44.8 to $80.4 \%$ (at $35^{\circ} \mathrm{C}$ ). The positive effect of increasing water content on OR may be explained through an increasing expansion and breaking of cell structures as well as its lubricating action which expedites oil release (Li et al., 1999).
With respect to fine solid content (FSC) the ANOVA analysis revealed that PT significantly affected ( $p=0.0275)$ FSC, while the other factors (SMC, RD and PS) had no significant effect ( $p>$ 0.05 ). Nevertheless, it is important to note that the highest values for FSC were obtained from samples 9 (10.32 g solid/100 g extract) and 20 (10.57 g solid/100 $\mathrm{g}$ extract) with a SMC of $3 \%$ and a PT of $50{ }^{\circ} \mathrm{C}$ and $75^{\circ} \mathrm{C}$, respectively (Table 1 ). While at higher SMC $(7 \%$ and $11 \%)$ the extracts presented lower FSC (4.34-7.39 g solid/100 g extract). According to Vargas-López et al., (1999), Singh et al., (2002) and Martínez et al., (2008) the FSC decreased when the SMC increased due the press cake becoming more compact, causing a smaller amount of sediment to pass through the barrel orifices to be co-extracted 
TABLE 2. Values of regression coefficients calculated for pistachio oil recovery in both designs.

(X1: seed moisture content, X2: restriction die, X3: pressing temperature and $\mathrm{X} 4$ : pressing speed)

\begin{tabular}{|c|c|c|}
\hline $\begin{array}{l}\text { Independent } \\
\text { variable }\end{array}$ & $\begin{array}{l}\text { Regression } \\
\text { coefficient }\end{array}$ & $\begin{array}{l}\text { Significance } \\
\text { level }(p)\end{array}$ \\
\hline \multicolumn{3}{|l|}{ First Design } \\
\hline Constant & -166.812 & \\
\hline $\mathrm{X}_{1}$ & $20.198 \pm 2.52$ & 0.0000 \\
\hline $\mathrm{X}_{2}$ & $22.354 \pm 2.52$ & 0.0414 \\
\hline $\mathrm{X}_{3}$ & $3.30736 \pm 2.52$ & 0.0000 \\
\hline $\mathrm{X}_{4}$ & $-0.37116 \pm 2.52$ & 0.0554 \\
\hline $\mathrm{X}_{1}^{2}$ & $-0.93669 \pm 4.80$ & 0.0020 \\
\hline $\mathrm{X}_{2}^{2}$ & $-1.65208 \pm 4.80$ & 0.6788 \\
\hline $\mathrm{X}_{3}{ }^{2}$ & $-0.02028 \pm 4.80$ & 0.0063 \\
\hline $\mathrm{X}_{4}^{2}$ & $-0.00162 \pm 4.80$ & 0.8706 \\
\hline $\mathrm{X}_{1} * \mathrm{X}_{2}$ & $-0.3894 \pm 6.55$ & 0.7496 \\
\hline $\mathrm{X}_{1} * \mathrm{X}_{3}$ & $-0.01897 \pm 6.55$ & 0.6977 \\
\hline $\mathrm{X}_{1} * \mathrm{X}_{4}$ & $0.034844 \pm 6.55$ & 0.5696 \\
\hline $\mathrm{X}_{2} * \mathrm{X}_{3}$ & $-0.1394 \pm 6.55$ & 0.4787 \\
\hline $\mathrm{X}_{2} * \mathrm{X}_{4}$ & $-0.0595 \pm 6.55$ & 0.8072 \\
\hline $\mathrm{X}_{3} * \mathrm{X}_{4}$ & $0.00528 \pm 6.55$ & 0.5896 \\
\hline $\mathrm{R}^{2}$ & & 91.23 \\
\hline \multicolumn{3}{|c|}{ Second Design } \\
\hline Constant & 94.3745 & \\
\hline $\mathrm{X}_{1}$ & $11.4494 \pm 2.26$ & 0.2395 \\
\hline $\mathrm{X}_{2}$ & $-39.8581 \pm 2.26$ & 0.0021 \\
\hline$X_{3}$ & $0.906219 \pm 2.26$ & 0.3337 \\
\hline $\mathrm{X}_{1}{ }^{2}$ & $-0.52094 \pm 3.19$ & 0.2396 \\
\hline $\mathrm{X}_{2}^{2}$ & $2.95375 \pm 3.19$ & 0.1137 \\
\hline $\mathrm{X}_{3}^{2}$ & $-0.00028 \pm 3.19$ & 0.9455 \\
\hline $\mathrm{X}_{1} * \mathrm{X}_{2}$ & $0.49625 \pm 3.19$ & 0.5570 \\
\hline $\mathrm{X}_{1} * \mathrm{X}_{3}$ & $-0.07725 \pm 3.19$ & 0.1010 \\
\hline $\mathrm{X}_{2} * \mathrm{X}_{3}$ & $-0.00862 \pm 3.19$ & 0.9175 \\
\hline $\mathrm{R}^{2}$ & & 86.60 \\
\hline
\end{tabular}

with oil. In fact, the SMC had a quadric effect on FSC (Figure 2).

Figure 2 also shows that when RD and PS increased, a reduction in FSC was observed due to a decrease in the compression degree of the material and a shorter residence time inside the pressing chamber. However, in all treatments evaluated, FSC showed low values, which was considered a positive trait since it facilitated subsequent operations of oil clarification. Therefore, considering that PS did not affect significantly OR and that the maximum OR coincided with the extreme SMC treatments (7 and $11 \%$ ), a new experimental design was made in order to find the extraction conditions which maximized OR (Table 3).

The new experimental design was elaborated considering the following factors and levels: SMC $\left(X_{1}: 8,10\right.$ and $\left.12 \%\right)$; PT $\left(X_{2}: 25,50\right.$ and $\left.75^{\circ} \mathrm{C}\right)$; and $\mathrm{RD}\left(X_{3}: 4,5\right.$ and $\left.6 \mathrm{~mm}\right)$ in order to determine an adequate combination to maximize OR and minimize FSC. The PS was kept constant at $20 \mathrm{rpm}$ because in these types of fruits, with high oil content, low pressure speeds are recommended in order to increase the time of the material permanence in the pressing chamber (Martinez et al., 2017a). This is in concordance with Rabadán et al. (2017), who found that low PS (17 rpm) increased oil yields, while high PS (96 rpm) led to low oil yields. A new Box-Behnken design with 16 experiments and four central points was developed to study the effect of these incoming factors. The experimental design and the response variables considered (OR, FSC, $\mathrm{OC}, \mathrm{PV}, \mathrm{FFAC}, \mathrm{K}_{232}, \mathrm{~K}_{270}$, LC and CC) are shown in Table 3.

The statistical analysis showed that RD significantly affected OR $(p<0.05)$; while SMC and PT had no significant effects $(p>0.05)$ (Table 2). Equation of the fitted model is:

$\mathrm{OR}=94.37+11.44 X_{1}-39.86 X_{2}+0.906 X_{3}-$ $0.521 X_{1}^{2}+2.954 X_{2}^{2}-0.0003 X_{3}^{2}+0.496 X_{1}^{*} X_{2}$ $-0.077 X_{1}^{*} X_{3}-0.0086 X_{2}^{*} X_{3}$

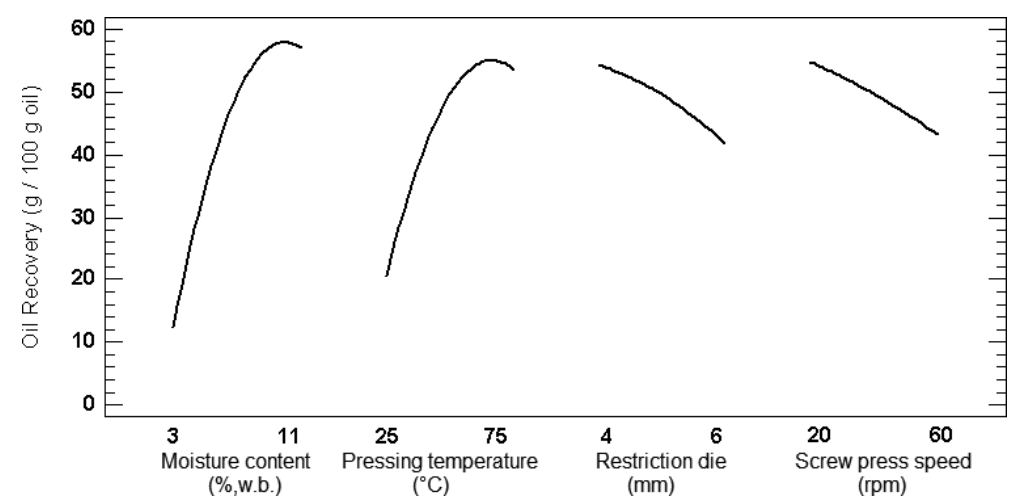

FIGURE 1. Main significant effects on oil recovery in pistachio oil extraction for preliminary Box- Behnken assay (First Design) 


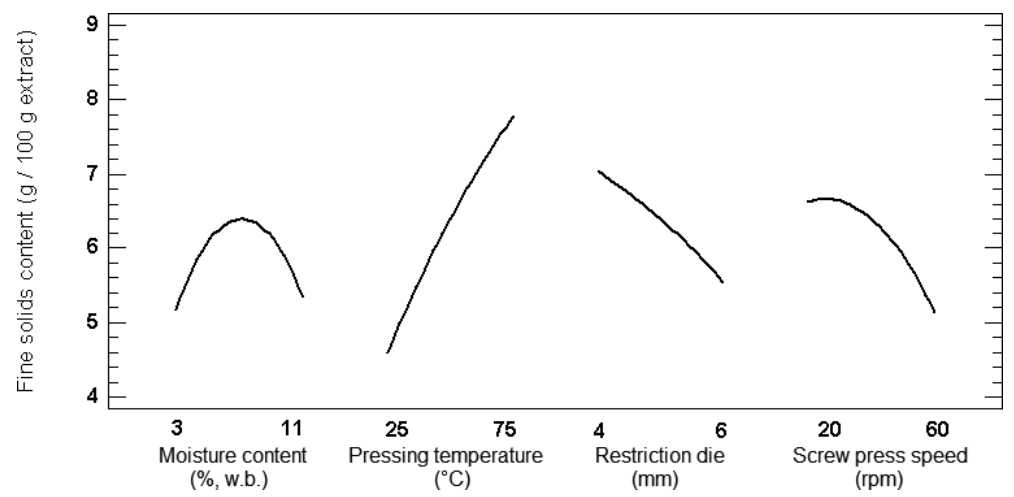

FIGURE 2. Main significant effects on fine solid contents in oil in pistachio oil extraction for preliminary Box- Behnken assay (First Design).

The coefficient of determination of the model $\left(\mathrm{R}^{2}\right)$ was able to explain $86.6 \%$ of the data variability. Figure 3 shows that a decrease in RD caused an increase in $\mathrm{OR}$, reaching a maximum value of approximately $70.88 \mathrm{~g} / 100 \mathrm{~g}$ of oil. On the other hand, although the effect of PT on OR was not significant, a directly proportional relationship was observed between the variables. SMC had a negative and positive quadratic effect on OR. At low SMC values OR was enhanced; while at high SMC the opposite effect was observed. This result is in agreement with Martinez et al., (2017a), who observed that walnut and almond oil extraction at high SMC $(12 \%)$ negatively affected OR due to insufficient friction during pressing.

It is important to highlight that the second experimental design (Table 3) enhanced OR values (53.61 $70.88 \mathrm{~g} / 100 \mathrm{~g}$ oil) compared to the preliminary assay (7.09 a $66.53 \mathrm{~g} / 100 \mathrm{~g}$ oil) (Table 1). In comparison with other works, Ling et al., (2016) obtained OR in the range of 32.95-33.27 g/100 g oil from roasted kernels and a value of $31.57 \mathrm{~g} / 100 \mathrm{~g}$ oil from raw kernels. On the other hand, Ortiz-Moreno et al., (2015) reported a maximum OR value with a screw press close to 40 g/100 g oil. Finally, Rabadán et al., (2017) reported OR to be approximately of $70 \mathrm{~g} / 100 \mathrm{~g}$ oil using the screw press at $75^{\circ} \mathrm{C}$ and $17 \mathrm{rpm}$ and Ojeda-Amador et al., (2018b) reported the best performance at $130{ }^{\circ} \mathrm{C}(68.5$ and $68.8 \mathrm{~g} / 100 \mathrm{~g}$ ) for Larnaka and Kerman pistachio varieties. Regarding the chemical quality of pistachio oil, Table 3 shows that the main chemical parameters were within the limits accepted by CODEX (1999) for virgin cold-pressed oils $\left(\mathrm{PV}<15\right.$ meq $\mathrm{O}_{2} / \mathrm{kg}$ oil and FFAC $<4 \mathrm{mg} \mathrm{KOH} / \mathrm{g}$ oil). PV and FFAC values varied from $0.05-0.28$ meq $\mathrm{O}_{2} / \mathrm{kg}$ oil and $0.21-0.33$ $\mathrm{mg} \mathrm{KOH} / \mathrm{g}$ oil, showing the absence of oxidative and hydrolytic deterioration. Specific extinction coefficient $\left(\mathrm{K}_{232}\right.$ and $\left.\mathrm{K}_{270}\right)$ values were within the ranges of 1.6 and 1.8 and 0.14 and0.16, respectively. These data show that the different extraction treatments had minimal effects on chemical quality parameters and oxidative stability.
Finally, lutein content (LC) was between 37.55$48.51 \mathrm{mg} / \mathrm{kg}$ oil, while chlorophyll content (CC) was between 18.3 and $26.37 \mathrm{mg} / \mathrm{kg}$ oil. These values were lower than those for pistachio oil reported by Martínez et al., (2016), who observed amounts between 41.4-69.6 and 48.5-57.5 mg/ kg oil for LC and $\mathrm{CC}$, respectively. According to Bellomo and Fallico (2007), pigment contents were strongly influenced by the degree of maturity and the origin of pistachio nuts.

In summary, different process conditions for pistachio oil extractions had negligible effects on the chemical quality parameters determined; however, OR was highly affected. The combination of factor levels which suggests maximum OR $(70.88 \mathrm{~g} / 100 \mathrm{~g}$ oil) and a low FSC (7.72g solids/100 g extract) is in acconcordance with treatment number 3 (8\% SMC, $4 \mathrm{~mm} \mathrm{RD}$ and $50^{\circ} \mathrm{C} \mathrm{PT}$ ) (Figure 4).

According to the desirability function the combination of process variables that optimized a maximum OR $\left(75.87 \mathrm{~g} / 100 \mathrm{~g}\right.$ oil) were: $8 \% \mathrm{SMC} ; 75^{\circ} \mathrm{C}$ PT; and $4 \mathrm{~mm} \mathrm{RD}$. This arrangement of factors was conducted according to the procedures mentioned above. Table 4 shows that no significant differences were found between the values predicted by the model $(75.87 \mathrm{~g} / 100 \mathrm{~g}$ oil $)$ and the experimental value observed $(79.61 \pm 2.56 \mathrm{~g} / 100 \mathrm{~g}$ oil $)$ for OR which proved a good fit of the model to the experimental data.

However, in order to obtain a cold-pressed pistachio oil, a new experimental design was made by adjusting PT to $40^{\circ} \mathrm{C}$ according to CODEX definitions (CODEX, 1999). In this case, the combination of each factor level which predicts a maximum OR $(69.89 \mathrm{~g} / 100 \mathrm{~g}$ oil) within the experimental values was $10 \% \mathrm{SMC}, 40{ }^{\circ} \mathrm{C} \mathrm{PT}$ and $4 \mathrm{~mm}$ RD. Table 4 shows that no significant differences were found between the value estimated by the model $(69.89$ $\mathrm{g} / 100 \mathrm{~g}$ oil) and the experimental value $(65.97 \pm 3.06$ $\mathrm{g} / 100 \mathrm{~g}$ oil) for OR, which indicates a good fit of the model to the experimental data. This value is higher than the OR reported by Ojeda-Amador et al., 


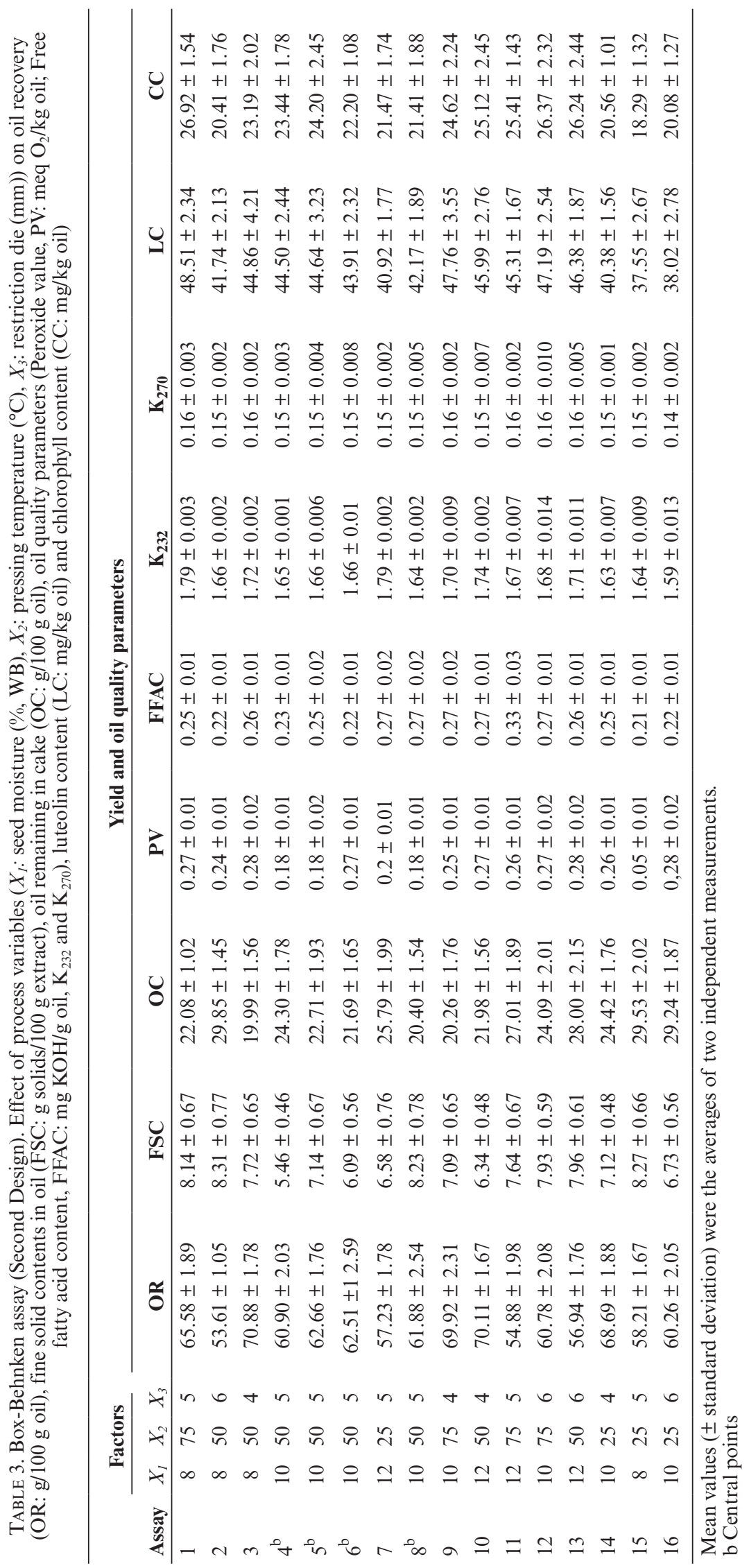




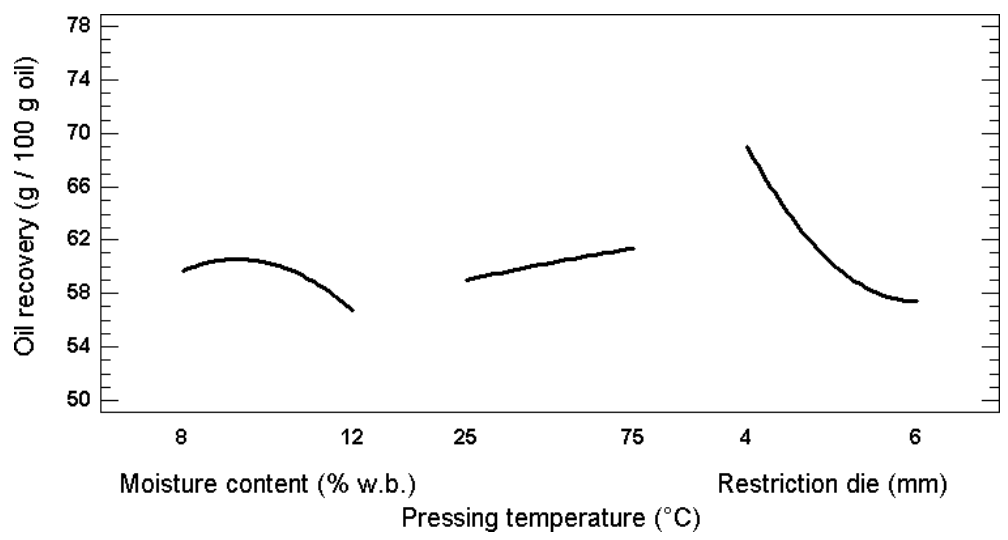

FIgURE 3. Main significant effects on oil recovery in pistachio oil extraction (Second Design).

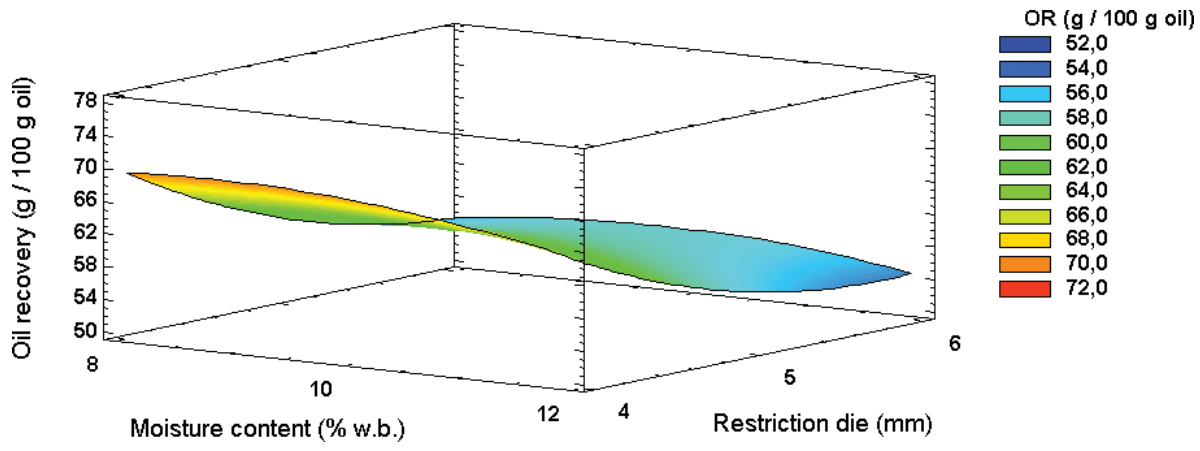

FIGURE 4. Effects of seed moisture content and restriction die on pistachio oil recovery at $50{ }^{\circ} \mathrm{C}$ pressing temperature (Second Design).

(2018b) for Larnaka and Kerman pistachio varieties $(56.1$ and $40.1 \mathrm{~g} / 100 \mathrm{~g}$ oil, respectively) under a similar extraction temperature $\left(40{ }^{\circ} \mathrm{C}\right)$. Moreover, the results demonstrated that even if the PT did not exert a significant influence on OR, it was observed in both optimizations that if this variable is modified, the SMC change in order to maximize OR. Additionally, SMC and PT modified the seed permeability and oil viscosity, respectively.

Table 4 presents the chemical parameters of the oil acquired from the optimized responses. As explained previously, the oil chemical quality (PV, FFAC, $\mathrm{k}_{232}$ and $\mathrm{k}_{270}$ ) was not negatively affected by the screw press extraction process. The oils obtained under both extraction conditions presented OSI values similar as those reported by Rabadán et al., (2017) (30.91 h). Regarding FAAC, the order of abundance was as follows: oleic acid (18: 1) $>$ linoleic acid (18:2) > palmitic acid (16: 0) > $\alpha$ Linolenic acid (18: 3) > palmitoleic acid (16:1) > stearic acid (C18: 0). Oleic acid was the major fatty acid, representing more than $50 \%$ of the total FA present in pistachio oil. These results are in agreement with those reported by Arena et al., (2007), Chahed et al., (2008) and Ojeda-Amador et al., (2018a) from Kerman and other pistachio varieties.

With respect to pistachio oil tocopherol composition, the first authors to report it were Kornsteiner et al., (2006) and Miraliakbari and Shahidi (2008). Although these authors partially agreed on the total tocopherol contents (298 and $334 \mathrm{mg} / \mathrm{kg}$ oil, respectively) in solvent extracted oils (hexane), the proportion of the individual components markedly differs between them. While Kornsteiner et al., (2006) reported major amounts of $\beta$ and $\gamma$ isoforms; Miraliakbari and Shahidi (2008) identified $\alpha$-tocopherol as the most abundant. In the present work the obtained oil had a total tocopherol content of $1000 \mathrm{mg} / \mathrm{kg}$ oil (Table 4), similar to the value obtained by Ojeda-Amador et al., (2018b) from roasted Larnaka pistachio oil $(830 \mathrm{mg} / \mathrm{Kg})$, but much higher than Ling et al., (2016) who reported a maximum of $367 \mathrm{mg} / \mathrm{Kg}$ oil. In acconcordance with these works $\gamma$-tocopherol was the most abundant isomer found and in agreement with Ojeda-Amador et al., (2018b), the increase in temperature during the extraction process did not significantly favor tocopherol solubility in oil. 
TABLE 4: Chemical parameters of oils extracted under processing conditions for maximum oil recovery ( $20 \mathrm{rpm}$ and $4 \mathrm{~mm}$ of restriction die) with: A) $10 \%$ seed moisture content and $40{ }^{\circ} \mathrm{C}$ pressing temperature, B) $8 \%$ seed moisture content and $75^{\circ} \mathrm{C}$ pressing temperature (OR: oil recovery, FSC: fine solid contents, OC: oil remaining in the cake, PV: peroxide value, FFAC: free fatty acid content, OSI: oxidative stability index)

\begin{tabular}{|c|c|c|}
\hline \multicolumn{3}{|c|}{ Optimal extraction conditions ( $20 \mathrm{rpm} ; 4 \mathrm{~mm})$} \\
\hline & $\mathrm{A}\left(10 \% ; 40{ }^{\circ} \mathrm{C}\right)$ & B $\left(8 \% ; 75^{\circ} \mathrm{C}\right)$ \\
\hline \multicolumn{3}{|l|}{ Oil yield parameters } \\
\hline OR (g/100 g oil) & $65.97^{\mathrm{a}} \pm 3.06$ & $79.61^{b} \pm 2.56$ \\
\hline FSC (g solids/100 g extract) & $10.32^{\mathrm{b}} \pm 1.23$ & $7.39^{\mathrm{a}} \pm 0.89$ \\
\hline OC $(g / 100 \mathrm{~g}$ oil $)$ & $26.69^{\mathrm{b}} \pm 2.54$ & $18.36^{\mathrm{a}} \pm 1.05$ \\
\hline \multicolumn{3}{|l|}{ Oil quality parameters } \\
\hline $\mathrm{PV}$ (meq $\mathrm{O}_{2} / \mathrm{kg}$ oil) & $0.26^{\mathrm{a}} \pm 0.03$ & $0.33^{\mathrm{a}} \pm 0.03$ \\
\hline FFAC (mg KOH/g oil) & $0.24^{\mathrm{a}} \pm 0.01$ & $0.31^{\mathrm{a}} \pm 0.02$ \\
\hline $\mathrm{K}_{232}$ & $1.72^{\mathrm{a}} \pm 0.03$ & $1.67^{\mathrm{a}} \pm 0.09$ \\
\hline $\mathrm{K}_{270}$ & $0.156^{\mathrm{a}} \pm 0.001$ & $0.156^{\mathrm{a}} \pm 0,001$ \\
\hline OSI (h) & $30.34^{\mathrm{a}} \pm 1.78$ & $31.81^{\mathrm{a}} \pm 1.56$ \\
\hline \multicolumn{3}{|l|}{ Main fatty acids (\%) } \\
\hline Palmitic (16:0) & $11.55^{\mathrm{a}} \pm 0.89$ & $11.60^{\mathrm{a}} \pm 1.78$ \\
\hline Palmitoleic (16:1) & $0.97^{\mathrm{a}} \pm 0.23$ & $0.883^{\mathrm{a}} \pm 0.08$ \\
\hline Stearic (18.0) & $0.37^{\mathrm{a}} \pm 0.02$ & $0.614^{\mathrm{a}} \pm 0.02$ \\
\hline Oleic $(18: 1)$ & $51.90^{\mathrm{a}} \pm 1.09$ & $54.65^{\mathrm{a}} \pm 2.01$ \\
\hline Linoleic (18:2) & $33.10^{\mathrm{a}} \pm 1.56$ & $31.90^{\mathrm{a}} \pm 1.65$ \\
\hline Linolenic (18:3) & $2.17^{\mathrm{a}} \pm 0.34$ & $0.95^{\mathrm{a}} \pm 0.10$ \\
\hline \multicolumn{3}{|l|}{ Tocopherols content (mg/kg oil) } \\
\hline$\alpha$-Tocopherol & $115^{\mathrm{a}} \pm 4.14$ & $113^{\mathrm{a}} \pm 2.10$ \\
\hline$\beta$-Tocopherol & $54^{\mathrm{a}} \pm 2.06$ & $55^{\mathrm{a}} \pm 1.11$ \\
\hline$\gamma$-Tocopherol & $777^{\mathrm{a}} \pm 35.3$ & $786^{\mathrm{a}} \pm 16.0$ \\
\hline$\delta$-Tocopherol & $61^{\mathrm{a}} \pm 1.32$ & $62^{\mathrm{a}} \pm 1.97$ \\
\hline \multicolumn{3}{|l|}{ Pigments content (mg/kg oil) } \\
\hline Luteolín & $43.53^{\mathrm{a}} \pm 0.92$ & $47.24^{\mathrm{a}} \pm 3.22$ \\
\hline Chlorophyll & $22.33^{\mathrm{a}} \pm 1.05$ & $26.93^{\mathrm{a}} \pm 2.34$ \\
\hline Total Phenol content (mg GA/kg oil) & $10.30^{\mathrm{a}} \pm 0.69$ & $11.28^{\mathrm{a}} \pm 0.78$ \\
\hline
\end{tabular}

Mean values ( \pm standard deviation) were the averages of two independent measurements. Values in each row with different superscript letters present significant differences $(p<0.05)$ among treatments (Fisher Test).

With respect to the total phenol contents (TPC) (Table 4), both extracted oils presented a lower TPC $(10.3-11.28 \mathrm{mg} \mathrm{GA} / \mathrm{Kg}$ oil) than those reported by Rabadán et al., (2017) (24.31 mg GA/kg oil), Ling et al., (2016) (38.7-49.5 mg GA/kg oil) and by Ojeda-Amador et al., (2018b) (approximately 16-76 $\mathrm{mg} \mathrm{GA} / \mathrm{kg}$ ). These differences among studies can be attributed to the fact that the TPC of nuts are affected not only by the genotype, but also the orchard location, harvest year, maturity index, processing, and storage conditions (Bolling et al., 2011). In addition, it has been reported (Ojeda-Amador et al., 2018b) that the solubility of phenolic compounds increases in the oil phase but at higher temperatures (between $80^{\circ} \mathrm{C}$ and $140{ }^{\circ} \mathrm{C}$ ) than those used in this study. The same authors have reported that this high temperature affects the oil pigment content, but a rise is not evident in this work between both temperatures studied (Table 4).

\section{CONCLUSIONS}

The Box-Behnken experimental design was employed to optimize pistachio oil extraction through screw-pressing operations. Seed moisture content, pressing temperature and restriction die resulted in the main processing parameters. The different combinations of process parameters did not generate oxidative and/or hydrolytic damage in the obtained oils; however, oil recovery was significantly affected. Oil recovery from pistachio seeds by pressing can be maximized by modifying moisture content $(8 \%$ or $10 \%$, w.b.), pressing temperature $\left(75^{\circ} \mathrm{C}\right.$ or $\left.40{ }^{\circ} \mathrm{C}\right), 4 \mathrm{~mm}$ restriction die and $20 \mathrm{rpm}$ 
screw-press speed to obtain oil recoveries of $79.61 \%$ or $65.97 \%$ of the total oil available, respectively.

\section{ACKNOWLEDGMENTS}

This research was financed with grants from Consejo de Investigaciones Científicas y Técnicas (CONICET), Secretaría de Ciencia y Tecnología de la Universidad Nacional de Córdoba (SeCyT UNC), Fund for Scientific Research and Technology (FONCyT - BID PICT 2014-2283) and Secretaría de Políticas Universitarias (SPU-Ministerio de Educación) from Argentina.

\section{REFERENCES}

Abdolshahi A, Majd MH, Rad JS, Taheri M, Shabani A, Teixeira da Silva JA. 2015. Choice of solvent extraction technique affects fatty acid composition of pistachio (Pistacia vera L.) oil. J. Food Sci. Technol. 52, 2422-2427. https://doi.org/10.1007/s13197-013-1183-8

Akinoso R, Raji AO. 2011. Optimization of oil extraction from locust bean using response surface methodology. Eur. J. Lipid Sc. Technol. 113, 245-252. https://doi.org/10.1002/ ejlt.201000354

Alvarez-Ortí M, Quintanilla C, Sena E, Alvarruiz A, Pardo JE. 2012. The effects of a pressure extraction system on the quality parameters of different virgin pistachio (Pistacia vera L. var. Larnaka) oil. Grasas Aceites 63 (3), 260-266. https://doi.org/10.3989/gya.117511

AOCS. 2009. Methods and recommended practices of the AOCS. USA: American Oil Chemist's Society.

Arena E, CampisiS, Fallico B, Maccarone E. 2007. Distribution of fatty acids and phytosterols as a criterion to discriminate geographic origin of pistachio seeds. Food Chem. 104, 403-408.

Bellomo MG, Fallico B. 2007. Anthocyanins, chlorophylls and xanthophylls in pistachio nuts (Pistacia vera) of different geographic origin. J. Food Comp. Anal. 20, 352-359. https://doi.org/10.1016/j.jfca.2006.04.002

Bolling BW, Chen CYO, McKay DL, Blumberg JB. 2011. Tree nut phytochemicals: Composition, antioxidant capacity, bioactivity, impact factors. A systematic review of almonds, Brazils, cashews, hazelnuts, macadamias, pecans, pine nuts, pistachios and walnuts. Nutrit. Res. Rev. 24, 244-275. https://doi.org/10.1017/S095442241100014X

Bullo M, Juanola-Falgarona M, Hernández-Alonso P, SalasSalvado J. 2015. Nutrition attributes and health effects of pistachio nuts. Br. J. Nut. 113, 79-93. https://doi. org/10.1017/S0007114514003250

ChahedT, Bellila A, Dhifi W, Hamrouni I, M'hamdi B, Kchouk ME, Marzouk B. 2008. Pistachio (Pistacia vera) seed oil composition: geographic situation and variety effects. Grasas Aceites 59 (1), 51-56. https://doi.org/10.3989/ gya.2008.v59.i1.490

Chang SK, Alasalvar C, Bolling BW, Shahidi, F. 2016. Nuts and their co-products: The impact of processing (roasting) on phenolics, bioavailability, and health benefits - A comprehensive review. J. Funct. Foods. 26, 88-122. https://doi. org/10.1016/j.jff.2016.06.029

Codex (1999). Section 2. Codex standards for fats and oils from vegetable sources. Codex Standard for Named Vegetable Oils (CODEXSTAN 210-1999). FAO/WHO.

Durmaz G, Gokmen V. 2011. Changes in oxidative stability, antioxidant capacity and phytochemical composition of Pistacia terebinthus oil with roasting. Food Chem. 128, 410-414. https://doi.org/10.1016/j.foodchem.2011.03.044

Jokic S, Vidovic S, Aladic K. 2014. Supercritical fluid extraction of edible oils. In Supercritical Fluids: Fundamentals, properties and applications (pp. 205e228). New York, USA: Nova Science Publishers.
Kornsteiner M, Wagner K, Elmadfa, I. 2006. Tocopherols and total phenolics in 10 different nut types. Food Chem. 98 (2), 381-387. https://doi.org/10.1016/j.foodchem. 2005.07.033

Li M, Bellmer DD, Brusewitz GH. 1999. Pecan kernel breakage and oil extracted by supercritical $\mathrm{CO}_{2}$ as affected by moisture content. J. Food Sci. 64, 1084-1088. https://doi. org/10.1111/j.1365-2621.1999.tb12287.x

Ling B, Yang X, Li R, Wang S. 2016. Physicochemical properties, volatile compounds, and oxidative stability of cold pressed kernel oils from raw and roasted pistachio (Pistacia vera L. Var Kerman). Eur. J. Lipid Sci. Technol. 118 (9), 1368-1379. https://doi.org/10.1002/ejlt.201500336

Maestri D, Martínez M, Bodoira R, Rossi Y, Oviedo A, Pierantozzi P, Torres M. 2015. Variability in almond oil chemical traits from traditional cultivars and native genetic resources from Argentina. Food Chem. 170, 55- 61. https:// doi.org/10.1016/j.foodchem.2014.08.073

Martínez ML, Mattea MA, Maestri DM. 2008. Pressing and supercritical carbon dioxide extraction of walnut oil. J. Food Eng. 88, 399-404. https://doi.org/10.1016/j. jfoodeng.2008.02.026

Martínez ML, Marín MA, Salgado Faller CM, Revol J, Penci MC, Ribotta PD. 2012. Chia (Salvia hispanica L.) oil extraction: study of processing parameters. J. Food Sci. Technol. 47, 78-82. https://doi.org/10.1016/j.lwt.2011.12.032

Martínez ML, Penci MC, Marin MA, Ribotta PD, Maestri DM. 2013. Screw press extraction of almond (Prunus dulcis (Miller) D.A. Webb): Oil recovery and oxidative stability. J. Food Eng. 119, 40-45. https://doi.org/10.1016/j. jfoodeng.2013.05.010

Martínez ML, Fabani MP, Baroni MV, MagriniHuaman RN, Ighani M, Maestri DM, Wunderlin, D, Tapia A, Feresin GE. 2016. Argentinian pistachio oil and flour: a potential novel approach of pistachio nut utilization. J. Food Sci. Technol. 53, 2260-2269. https://doi.org/10.1007/ s13197-016-2184-1

Martínez ML, Bordón MG, Bodoira RM, Penci MC, RibottaPD, Maestri DM. 2017a. Walnut and almond oil screw-press extraction at industrial scale: Effects of process parameters on oil yield and quality. Grasas Aceites 68 (4), 216-225. https://doi.org/10.3989/gya.0554171

Martínez ML, Bordón MG, Lallana RL, Ribotta PD, Maestri DM. 2017b. Optimization of Sesame Oil Extraction by Screw-Pressing at Low Temperature. Food Biop. Technol. 10, 1113-1121. https://doi.org/10.1007/s11947-017-1885-4

Mattea M.A. 1999. Fundamentos sobre el prensado de semillas oleaginosas. Aceites y Grasas 427-431.

Minguez-Mosquera MI, Rejano L, Gandul B, Sánchez A, Garrido J. 1991. Color pigment correlation in virgin olive oil. J. Am. Oil Chem. Soc. 68, 332-336. https://doi. org/10.1007/BF02657688

Miraliakbari H, Shahidi F. 2008. Lipid class compositions, tocopherols and sterols of tree nut oils extracted with different solvents. J. Food Lipids. 15 (1), 81-96. https://doi. org/10.1111/j.1745-4522.2007.00104.x

Montgomery DC. 2005. Introduction to factorial designs, in Montgomery DC (Ed.) Design and Analysis of Experiments. John Wiley \& Sons Inc., New York, pp. 160-197.

Ojeda-Amador RM, Fregapane G, Salvador MD. 2018a. Composition and properties of virgin pistachio oils and their by-products from different cultivars. Food Chem. 240, 123-130. https://doi.org/10.1016/j.foodchem.2017.07.087

Ojeda-Amador RM, Trapani S, Fregapane G, Salvador MD. 2018b. Phenolics, tocopherols, and volatiles changes during virgin pistachio oil processing under different technological conditions. Eur.J. Lipid Sci. Technol. 120, 1-11. https://doi.org/10.1002/ejlt.201800221

Papetti A, Daglia M, Aceti C, Quaglia M, Gregotti C, Gazzani G. 2006. Isolation of an in vitro and ex vivo antiradical melanoidin from roasted barley. J. Agric. Food Chem. 54, 1209-1216. https://doi.org/10.1021/jf058133x

Pérez-Jiménez J, Neveu V, Vos F, Scalbert A. 2010. Identification of the 100 richest dietary sources of polyphenols: An application of the Phenol-Explorer database. Eur. J. Clin. Nut. 64, 112-120. https://doi.org/10.1038/ejen.2010.221 
Que F, Mao L, Fang X, Wu T. 2008. Comparison of hot air-drying and freeze-drying on the physicochemical properties and antioxidant activities of pumpkin (Cucurbita moschata Duch.) flours. Int. J. Food Sci. Technol. 43, 1195-1201. https://doi. org/10.1111/j.1365-2621.2007.01590.x

Rabadán A, Alvarez-Ortí M, Gómez R, Alvarruiz A, Pardo JE. 2017. Optimization of pistachio oil extraction regarding processing parameters of screw and hydraulic presses. $L W T$ - Food Sci. Technol. 83, 79-85. https://doi.org/10.1016/j. lwt.2017.05.006

Savoire R, Lanoisellé JL, Vorobiev E. 2013. Mechanical continuous oil expression from oilseeds: a review. Food Biop. Technol. 6, 1-16. https://doi.org/10.1007/ s11947-012-0947-x

Schulze-Kaysers N, Feuereisen MM, Schieber A. 2015. Phenolic compounds in edible species of the Anacardiaceae family - a review. RSC Advances 5, 73301-73314. https://doi. org/10.1039/C5RA11746A

Seferoglu S, Seferoglu SG, Tekintas FE, Balta F. 2006. Biochemical composition influenced by different locations in Uzun pistachio cv. (Pistachia vera L.) grown in Turkey. J. Food Comp. Anal. 19, 461-465. https://doi.org/10.1016/j. jfca.2006.01.009

Sena-Moreno E, Pardo JE, Catalán L, Gómez R, PardoGiménez A, Alvarez-Ortí M. 2015. Drying temperature and extraction method influence physicochemical and sensory characteristics of pistachio oils. Eur. J. Lipid Sci. Technol. 117, 684-691. https://doi.org/10.1002/ ejlt.201400366

Singh J, Bargale PC. 2000. Development of a small capacity double stage compression screw press for oil expression. J. Food Eng. 43, 75-82. https://doi.org/10.1016/ S0260-8774(99)00134-X

Singh KK, Wiesenborn DP, Tostenson K, Kangas N. 2002. Influence of moisture content and cooking on screw pressing of crambeseed. J. Am. Oil Chem. Soc. 79, 165-170. https://doi.org/10.1007/s11746-002-0452-3
Tomaino A, Martorana M, Arcoraci T, Monteleone D, Giovinazzo C Saija A. 2010. Antioxidant activity and phenolic profile of pistachio (Pistacia vera L., variety Bronte) seeds and skins. Biochimie 92, 1115-1122. https:// doi.org/10.1016/j.biochi.2010.03.027

Torres MM, Pierantozzi P, Cáceres ME, Labombarda P, Fontanazza G, Maestri DM. 2009. Genetic and chemical assessment of Arbequina olive cultivar grown in Córdoba province, Argentina. J. Sci. Food Agric. 89, 523-530. https://doi.org/10.1002/jsfa.3483

Tsantili E, Takidelli C, Christopoulos MV, Lambrinea E, Rouskas D, Roussos PA. 2010. Physical, compositional and sensory differences in nuts among pistachio (Pistachia vera L.) varieties. Scientia Hortic. 125, 562-568. https://doi. org/10.1016/j.scienta.2010.04.039

Vargas-Lopez JM, Wiesenborn D, Tostenson K, Cihacek L. 1999. Processing of crambe for oil and isolation of erucic acid. J. Am. Oil Chem. Soc. 76, 801-809. https://doi. org/10.1007/s11746-999-0069-4

Venkatachalam M, Sathe SK. 2006. Chemical Composition of Selected Edible Nut Seeds. J. Agric. Food Chem. 54, 47054714. https://doi.org/10.1021/jf0606959

Vujasinovic V, Djilas S, Dimic E, Basic Z, Radocaj O. 2012. The effect of roasting in the chemical composition and oxidative stability of pumpkin oil. Eur. J. Lipid Sci. Technol. 114, 568-574. https://doi.org/10.1002/ejlt.201100158

Wiesenborn D, Doddapaneni R, Tostenson K, Kangas N. 2001. Cooking indices to predict screw-press performance for crambe seed. J. Am. Oil Chem. Soc. 78, 467-471. https:// doi.org/10.1007/s11746-001-0287-y

Wijesundera C, Ceccato C, Fagan P, Shen Z. 2008. Seed roasting improves the oxidative stability of canola (B. napus) and mustard (B. juncea) seed oils. Eur. J. Lipid Sci. Technol. 110, 360-367. https://doi.org/10.1002/ejlt.200700214

Zheng Y, Wiesenborn DP, Tostenson K, Kangas N. 2003. Screw pressing of whole and dehulled flaxseed for organic oil. $J$. Am. Oil Chem. Soc. 80, 1039-1045. https://doi.org/10.1007/ s11746-003-0817-7 